\title{
The Right of Access to Child Custody and Dependency Cases
}

\author{
Mary McDevitt Gofen $\dagger$
}

Child custody and dependency cases require judges to decide the fundamental rights of children and parents. ${ }^{1}$ Although disputes often arise at divorce, they also appear in many other types of proceedings, including state-initiated actions against allegedly abusive or neglectful parents, disputes over surrogacy contracts, and other juvenile court proceedings.

Most courts decide disputes based on the "best interests of the child," a standard that is ambiguous and sometimes results in judicial abuse. ${ }^{2}$ Because this standard gives judges tremendous discretion in deciding custody and dependency cases, an informed public is crucial to serve as a check on the system. ${ }^{3}$

$\dagger$ B.A. 1987, Stanford University; J.D. Candidate 1995, The University of Chicago.

1 See, for example, Santosky v Kramer, 455 US 745, 753 (1982) (recognizing the "fundamental liberty interest of natural parents in the care, custody, and management of their child," an interest protected by the Due Process Clause of the Fourteenth Amendment). See also Smith v Organization of Foster Families, 431 US 816, 845 (1977) (recognizing that natural families, but not foster families, have a "liberty interest in family privacy," the source of which is "to be sought . . . in intrinsic human rights").

2 For example, although custody awards are not supposed "to be used as punishment for parental misconduct, some jurisdictions appear to have awarded custody for that purpose." Lynn D. Wardle, Christopher L. Blakesley, and Jacqueline Y. Parker, 4 Contemporary Family Law § 39:07 at 36 (Callaghan, 1988), citing Schexnayder $v$ Schexnayder, 371 S2d 769 (La 1979) (apparently endorsing punishment for past misconduct under the guise of the best interest of the child standard). See also James C. Black and Donald J. Cantor, Child Custody 3 (Columbia, 1989) (suggesting that some judges may grant custody exclusively to women under the notion that "women raise children and men work").

${ }^{3}$ See, for example, Robert Grant, Law and the Family v, 183-84 (Scribner's Sons, 1919). Judge Grant, a probate judge in Boston, included in his treatise on family law a cogent description of his far-reaching judicial powers:

A Probate Judge who outlives you

May break your will-yes, tax it, too.

Concerning various other things,

His power outrivals that of kings:

If he decides you are insane,

All your remonstrances are in vain.

...

Your children, when you prove unfit,

Are whisked away by sovereign writ.

... 
Nonetheless, the right of the press to attend custody proceedings has not been firmly established. ${ }^{4}$

Several lower courts have held that the press and public have a qualified right of access to custody proceedings. Some of these courts have granted the press access to such cases but prohibited the disclosure of the identities of the children involved. Other lower courts, however, have held that no right of access exists and have closed courtroom doors to the press and public. The Supreme Court has not yet addressed the issue in the context of custody proceedings. But in a recent series of cases, the Supreme Court has recognized and gradually broadened the First Amendment right of access to other judicial proceedings.

This Comment addresses whether the press has a First Amendment right of access to child custody and dependency cases. Part.I discusses the Supreme Court cases dealing with the First Amendment right of access to criminal cases. Part II summarizes the analyses of the lower courts determining access to civil cases generally and custody and dependency cases in particular. Part III argues that, contrary to the strict construction employed by certain courts, the constitutional objectives underlying the Supreme Court's right-of-access decisions require that a qualified right of access encompass child custody and dependency cases. Finally, Part IV examines the scope of the right of access to custody cases, focusing on the "qualified" nature of that right and on the limitations courts may impose without violating the right. This Comment argues that the press should always be able to attend child custody proceedings, but under certain circumstances courts may condition this access on limited reporting restrictions in order to protect the parties' privacy.

In short, it may be truly said

He has you living, has you dead.

The moral is-as on you trudge,

Propitiate the Probate Judge.

Id at v-vi.

1 Under the First Amendment and the common law, the press and the public have an equal right of access to the courts. See Webster Groves School District v Pulitzer Publishing Co., 898 F2d 1371, 1374 n 3 (8th Cir 1990), citing Nixon v Warner Communications, Inc., 435 US 589, 610 (1978); Edward A. Sherman Publishing Co. v Goldberg, 443 A2d 1252, 1258 (RI 1982). This Comment focuses on the First Amendment rights of newspapers and other print media covering child custody and dependency proceedings; it does not discuss the rights of broadcast media. 


\section{SUPREME COURT RECOGNITION OF A FirSt AMENDMENT RIGHT OF ACCESS}

The United States Supreme Court has addressed the question of press access to court proceedings on four separate occasions. In Richmond Newspapers, Inc. $v$ Virginia, the Court held that the public and press enjoy a First Amendment right to attend criminal trials. ${ }^{5}$ The Richmond Newspapers decision arose from a murder prosecution in which the trial court excluded the public and press at the request of the defense and without objection from the prosecution. Pointing out that the judge failed to consider less drastic measures, two newspaper reporters made a motion to vacate the closure order. But the court denied the motion. ${ }^{6}$ On appeal, the United States Supreme Court reversed. ${ }^{7}$

In a plurality opinion, the Court began its analysis of the issue of access by considering the history of the criminal trial in Anglo-American justice. ${ }^{8}$ In tracing that history, the Court noted that in England and the American colonies the "very nature of a criminal trial was its openness to those who wished to attend."

The plurality also noted that open trials serve several societal interests. First, open trials operate as a "nexus between openness, fairness, and the perception of fairness" that ensures that all parties are treated fairly, discourages perjury, and enhances public confidence in the judicial system. ${ }^{10}$ Second, public trials offer a "significant community therapeutic value": allowing people to see justice done reassures them that society functions properly and reduces the urge toward vigilantism. ${ }^{11}$ The Court explained that " $[t]$ he crucial prophylactic aspects of the administration of justice cannot function in the dark; no community catharsis can occur if justice is 'done in a corner [or] in any covert manner."'12 Finally, openness educates the public about the judi-

5 448 US 555, 580 (1980) (plurality opinion). Seven members of the Court found some First Amendment right of access, although there was no opinion in which more than three Justices joined.

6 Id at 561.

7 Id at 581.

8 Id at 564-69.

9 Id at 568 .

10 Id at 569-70.

11 Id at 570-72

12 Id at 571, quoting the 1677 Concessions and Agreements of West New Jersey, reprinted in Richard L. Perry, ed, Sources of Our Liberties: Documentary .Origins of Individual Liberties in the United States Constitution and Bill of Rights 184, 188 (American Bar Foundation, 1959). The Richmond Newspapers Court explained:

A result considered untoward may undermine public confidence, and where the trial 
ciary and its administration. ${ }^{13}$ The Court stated:

People in an open society do not demand infallibility from their institutions, but it is difficult for them to accept what they are prohibited from observing. When a criminal trial is conducted in the open, there is at least an opportunity both for understanding the system in general and its workings in a particular case .... ${ }^{14}$

By educating the public, openness also serves to increase public respect for the law. ${ }^{15}$

Thus, relying on historical evidence and the societal benefits of such a rule, the plurality held that a presumption of openness attaches to criminal trials. ${ }^{16}$ Noting the absence of an express right of access in either the Constitution or the Bill of Rights, the Court held that the right to attend criminal trials is implicit in the specific guarantees of the First Amendment, ${ }^{17}$ which "share a common core purpose of assuring freedom of communication on matters relating to the functioning of government."18 An order to close a criminal trial would therefore require "an overriding interest articulated in findings," but the judge, after making such findings, may "in the interest of the fair administration of justice, impose reasonable limitations on access to a trial." ${ }^{\text {19 }}$ Because the trial court made no findings to support closure, did not inquire whether alternative measures could have achieved the same results as the closure order, and failed to acknowledge a First Amendment right of access, the Court reversed the closure order. $^{20}$

Two years after Richmond Newspapers, the Supreme Court clarified and strengthened the First Amendment right of access

has been concealed from public view an unexpected outcome can cause a reaction that the system at best has failed and at worst has been corrupted. To work effectively, it is important that society's criminal process "satisfy the appearance of justice," and the appearance of justice can best be provided by allowing people to observe it.

448 US at 571-72, quoting Offutt $v$ United States, 348 US 11, 14 (1954).

13 Richmond Newspapers, 448 US at 572.

14 Id.

15 Id, citing John Henry Wigmore, 6 Evidence $\S 1834(2)$ at 438 (Little, Brown, 1976)

(James H. Chadbourne revision).

${ }^{16}$ Richmond Newspapers, 448 US at 573.

17 Id at 580 .

18 Id at 575.

19 Id at 581 \& $n 18$.

20 Id at 581 . 
to criminal trials in Globe Newspaper Co. $v$ Superior Court. ${ }^{21}$ In Globe Newspaper, the Court held that it was unconstitutional to require the closure of the criminal trials of alleged sex offenders during the testimony of minor victims..$^{22}$ Recognizing the holding of the Richmond Newspapers plurality that the right of access to criminal trials is not absolute, the Court stated that:

Where, as in the present case, the State attempts to deny the right of access in order to inhibit the disclosure of sensitive information, it must be shown that the denial is necessitated by a compelling governmental interest, and is narrowly tailored to serve that interest. ${ }^{23}$

The Court determined that the state has a compelling interest in "safeguarding the physical and psychological well-being of a minor ...." It concluded, however, that this compelling interest does not justify a mandatory closure rule because closure is not always the least restrictive means of furthering that interest. ${ }^{25}$ Thus, after Globe Newspaper, courts must decide the issue of press access to a criminal trial on a case-by-case basis. ${ }^{26}$

The Supreme Court extended the First Amendment right of access beyond the criminal trial itself to the process of jury selection in Press-Enterprise Co. $v$ Superior Court of California ("Press-Enterprise I"). ${ }^{27}$ In Press-Enterprise $I$, the trial court in a rape and murder prosecution closed most of the six-week-long voir dire proceedings. The court later refused to release any portion of the court's voir dire transcript. ${ }^{28}$

In its analysis, the Supreme Court again considered two factors. First, the court examined the history of the jury selection process-tracing it from its inception before the Norman Conquest to the present-and cited evidence that the process has been presumptively open with few exceptions. ${ }^{29}$ Second, the

21 457 US 596 (1982).

${ }^{22}$ Id at $600,610-11$.

${ }^{23}$ Id at 606-07.

24 Id at 607.

25 Id at 607-09.

${ }^{26}$ Id at $608 \& \mathrm{n} 20$. The Court noted with approval that "the plurality opinion in Richmond Newspapers suggested that individualized determinations are always required before the right of access may be denied ...." Id, citing Richmond Newspapers, 448 US at 581.

27464 US 501 (1984).

${ }_{28}^{28}$ Id at 503-04.

29 Id at 505-08. 
Court explained the societal benefits of openness, stating that its value

lies in the fact that people not actually attending trials can have confidence that standards of fairness are being observed; the sure knowledge that anyone is free to attend gives assurance that established procedures are being followed and that deviations will become known. ${ }^{30}$

Thus, "[c]losed proceedings, although not absolutely precluded, must be rare and only for cause shown that outweighs the value of openness." ${ }^{31}$ To overcome the presumption of openness, the trial court must articulate specific "findings that closure is essential to preserve higher values and is narrowly tailored to serve that interest." ${ }^{\prime 32}$ Even when limited closure is essential, the court may be required to release a transcript of the proceedings. ${ }^{33}$ Thus, since the trial court's failure to consider alternatives to full closure rendered its closure of the voir dire proceedings unconstitutional, the Supreme Court vacated the judgment and remanded the case. ${ }^{34}$

The most recent Supreme Court decision on the First Amendment right of access, Press-Enterprise Co. $v$ Superior Court ("Press-Enterprise II"), extended the right to preliminary hearings. ${ }^{35}$ This case arose from a California magistrate's decision to exclude the press and public from a forty-one-day preliminary hearing conducted to determine whether the defendant had to answer murder charges. ${ }^{36}$ As with the previous line of right-ofaccess cases, the Court looked to "two complementary considerations. ${ }^{37}$ First, the Court examined the historical evidence and determined that preliminary hearings were traditionally open to the public. ${ }^{38}$ Second, the Court considered the virtues of public access, concluding that the same values that led the Court to find a right of access to criminal trials applied equally in the context of preliminary proceedings. ${ }^{39}$ Thus, the Court held that a quali-

${ }^{30}$ Id at 508.

31 Id at 509.

32 Id at 510 .

33 Id at 512.

34 Id at $511,513$.

35478 US 1 (1986).

36 Id at 3-5.

37 Id at 8.

38 Id at 10-11.

${ }^{39}$ Id at 11-13. The Court emphasized that if a magistrate in a preliminary hearing determines that probable cause exists, the accused is bound over for trial and-in a 
fied right of access attaches to preliminary hearings. The proceedings cannot be closed unless specific articulated findings demonstrate that "closure is essential to preserve higher values and is narrowly tailored to serve that interest."40

In summary, the Supreme Court has developed a two-part test based on the historical tradition and societal benefits of openness to determine whether a qualified right of access attaches to judicial proceedings. First, a court must determine whether the proceeding has "historically been open to the press and public."11 Second, the court must determine whether access "plays a significant positive role in the functioning of the particular process in question." ${ }^{22}$ If the judicial proceeding passes these tests, a qualified First Amendment right of access attaches. The right may be overcome only if "closure is essential to preserve higher values and is narrowly tailored to serve that interest. ${ }^{\text {"43 }}$ Moreover, the Supreme Court has never found a value so compelling that it allows complete closure.

\section{LOWER COURT RECOGNITION OF THE FIRST AMENDMENT RIGHT OF ACCESS TO CIVIL, CHILD CUSTODY, AND DEPENDENCY PROCEEDINGS}

Although the Supreme Court has not yet explicitly considered whether there is a right of access to noncriminal proceedings, several appellate courts have found that the right extends to civil cases. ${ }^{44}$ These courts relied on the Supreme Court's own

majority of cases-pleads guilty. Thus, "the preliminary hearing is often the final and most important step in the criminal proceeding." Id at 12. Further, "in many cases [it] provides the sole occasion for public observation of the criminal justice system." Id, quoting San Jose Mercury News v Municipal Court, 30 Cal 3d 498, 179 Cal Rptr 772, 780 (1982).

40 Press-Enterprise $I I, 478$ US at 13-14, quoting Press-Enterprise $I, 464$ US at 510.

41 Press-Enterprise $I I, 478$ US at 8.

42 Id.

4 Id at 13-14, quoting Press-Enterprise I, 464 US at 510.

4 See, for example, Westmoreland v CBS, 752 F2d 16, 23 (2d Cir 1984) ("[T]he First Amendment does secure to the public and to the press a right of access to civil proceedings... ."); Publicker Industries, Inc. $v$ Cohen, 733 F2d 1059, 1070-71 (3d Cir 1984) ("A presumption of openness inheres in civil trials as in criminal trials."); In re Continental Illinois Securities Litigation, 732 F2d 1302, 1308 (7th Cir 1984) ("[T] he policy reasons for granting public access to criminal proceedings apply to civil cases as well."); Brown \& Williamson Tobacco Corp. $v$ FTC, 710 F2d 1165, 1178 (6th Cir 1983) ("The Supreme Court's analysis of the justifications for access to the criminal courtroom apply as well to the civil trial."); Rushford v New Yorker Magazine, Inc., 846 F2d 249, 253 (4th Cir 1988) (The First Amendment right of access "should also apply to documents filed in connection with a summary judgment motion in a civil case."). 
historical analysis indicating that civil cases have always been presumptively open. ${ }^{45}$ They also emphasized that concerns for fairness, public confidence, and informed governance apply to both the criminal and civil contexts. ${ }^{46}$

Although federal appellate courts have not yet addressed whether a constitutional or common law right of access attaches specifically to child custody and dependency proceedings, several state courts have addressed the issue. In Barron $v$ Florida Freedom Newspapers, Inc., the Florida Supreme Court held that state common law required a presumption of openness in all court proceedings, including divorce cases. ${ }^{47}$ The court stated:

A trial is a public event. What transpires in the court room is public property .... There is no special perquisite of the judiciary which enables it, as distinguished from other institutions of democratic government, to suppress, edit, or censor events which transpire in proceedings before it. ${ }^{48}$

According to Barron, a court should order closure only when necessary "to comply with established public policy set forth in the constitution, statutes, rules, or case law"; "to protect trade secrets"; "to protect a compelling governmental interest"; "to obtain evidence to properly determine legal issues in a case"; or to avoid "substantial injury" to innocent third parties or certain common law or privacy rights of a party to the litigation. ${ }^{49}$ Further, the closure order must be the least restrictive means necessary to accomplish its purpose. ${ }^{50}$ Thus, the Florida courts acknowledge both a common law and a constitutional right of ac-

45 See, for example, Publicker Industries, 733 F2d at 1068-69; Brown \& Williamson Tobacco, 710 F2d at 1178-79. In Richmond Newspapers, the plurality wrote that "[w] hether the public has a right to attend trials of civil cases is a question not raised by this case, but we note that historically both civil and criminal trials have been presumptively open." 448 US at 580 n 17 . Justice Stewart, in his concurring opinion, stated that "the First and Fourteenth Amendments clearly give the press and the public a right of access to trials themselves, civil as well as criminal." Id at 599 (Stewart concurring).

${ }^{46}$ See, for example, Continental Illinois, 732 F2d at 1308-10; Brown \& Williamson Tobacco, 710 F2d at 1178-79.

47531 S2d 113, 118-19 (Fla 1988).

48 Id at 116 (ellipsis in original), quoting Craig $v$ Harney, 331 US 367, 374 (1947).

$49531 \mathrm{~S} 2 \mathrm{~d}$ at 118 .

${ }^{50}$ Id. See also M.R. $v$ Florida Department of Health and Rehabilitation Services, 19 Media L Rptr (BNA) 1189, 1190 (Fla Cir Ct 1991) (allowing a newspaper access to the court file in a child custody case, holding that the public's interest in knowing and evaluating the state's actions in protecting children outweighed the privacy interests of the parents and the child, and finding that the court could adequately protect any such privacy interest by redacting from the files the names of the individuals involved). 
cess to civil proceedings. Lower Florida courts have applied this presumption of openness to child custody proceedings. ${ }^{51}$

Many state courts have applied the First Amendment analysis outlined in Richmond Newspapers and its progeny to the issue of the right of access to child custody and dependency proceedings. At least one court has found that under the Supreme Court's two-part test focusing on the historical tradition and the societal benefits of openness in a given context, such a right exists. In New Jersey Division of Youth \& Family Services $v$ J.B., the New Jersey Supreme Court held that custody cases should be open to the public and press. ${ }^{52}$ The court first found that "[t]he history of civil jurisprudence, like that of criminal law, reveals a tradition of public access." ${ }^{\text {33 }}$ The court stated that the historical materials relied on by the plurality in Richmond Newspapers applied to civil as well as criminal trials. ${ }^{54}$ The New Jersey Supreme Court also found that, as with criminal cases, press access to civil cases serves the First Amendment's "core purpose of assuring freedom of communication on matters relating to the functioning of government...."55 The court concluded that this right of access could be overcome only by an important state interest. $^{56}$

Conversely, other lower courts applying the Supreme Court's two-part First Amendment analysis to child custody cases have held that no presumptive right of access exists. ${ }^{57}$ In In re T.R.,

51 See, for example, M.R., 19 Media L Rptr (BNA) at 1190.

52120 NJ 112, 576 A2d 261, 269-70 (1990). See also In re Chase, 112 Misc 2d 436, 446 NYS2d 1000, 1009 (Fam Ct 1982) (finding that the right of access extends to juvenile delinquency proceedings).

${ }_{53} 576$ A2d at 266, citing Publicker Industries, 733 F2d at 1068-70.

54 $576 \mathrm{~A} 2 \mathrm{~d}$ at 266.

65 Id, quoting Richmond Newspapers, 448 US at 575.

${ }^{56} 576$ A2d at 267, 269. The court indicated that certain types of custody proceedings-those initiated by the Division of Youth and Family Services ("DYFS") for termination of parental rights or for temporary custody-are presumptively closed. Id at 269-70. Such a presumption was justified, the court stated, by the frequency with which DYFS cases involve allegations of child abuse and by the compelling state interest in protecting victims of child abuse from the trauma and embarrassment of testifying in an open courtroom. Id at 269. However, the court held that this presumption of closure was not absolute: "Members of the public, including the press, must be free to make application to the trial court to be permitted to attend DYFS proceedings." Id. Confronted with such an application, "the court must balance the public's right of access to judicial proceedings against the State's interest in protecting children from the possible detrimental effects of revealing to the public allegations and evidence relating to parental neglect and abuse." Id. Recognizing that J.B. did not involve any allegations of abuse, but rather related to the father's mental health and capacity to carry out his duties as a parent, the court held that press access was proper. Id at 270 .

${ }^{57}$ See In re T.R., 52 Ohio St 3d 6, 556 NE2d 439, 448-50 (1990); San Bernardino 
for example, the Ohio Supreme Court stated that the Press-Enterprise II test focusing on the historical tradition and societal benefits of openness accurately defines the limits of constitutionally protected access to all court proceedings. ${ }^{58}$ In applying this test, the court first noted that the modern juvenile court system did not exist at common law, "though it has roots in the commonlaw doctrine of parens patriae, which made the courts of chancery responsible for the protection of infants. ${ }^{\text {} 59}$ Stating that juvenile proceedings are typically informal, private, and based on an inquisitorial model rather than an adversarial one, the court noted that juvenile proceedings have historically been closed to the public. ${ }^{60}$ Furthermore, the court found that public access to custody proceedings in juvenile court offered only limited societal benefits. The court stated, "Custody disputes generally require the courts to delve into the private relations of parents and children. While curiosity may be incited by custody cases involving bizarre facts or famous persons, this does not necessarily translate into a significant positive public role." ${ }^{361}$ The court concluded that a First Amendment right of access does not attach to child custody proceedings. ${ }^{62}$ The court held that custody cases are neither presumptively open nor presumptively closed. Rather, a court must engage in a case-by-case analysis and restrict public access if "it finds that: (1) there exists a reasonable and substantial basis for believing that public access could harm the child or endanger the fairness of the proceeding, and (2) the potential for harm outweighs the benefits of public access." ${ }^{163}$

County Department of Public Social Services v Superior Court, 232 Cal App 3d 188, 283 Cal Rptr 332, 338-43 (1991); In re Katherine B., 189 AD2d 443, 596 NYS2d 847, 851 (1993). See also Edward A. Sherman Publishing Co. v Goldberg, 443 A2d 1252, 1258 (RI 1982).

${ }_{58} 556 \mathrm{NE} 2 \mathrm{~d}$ at 446 ("[W]e adopt this test and hold that the public's qualified right of access attaches to those hearings and proceedings in all courts which have historically been open to the public, and in which public access plays a significant positive role.").

${ }^{69}$ Id at 448. According to the court, the first juvenile court in Ohio was established in 1902. Id.

${ }_{60}$ Id at 448-49. "[A]ll 50 states have statutes that provide in some way for confidentiality' in juvenile proceedings." Id, quoting Smith v Daily Mail Publishing Co., 443 US 97, 105 (1979)

${ }_{61}$ T.R., 556 NE2d at $449-50$.

62 Id at 450.

63 Id at 451. 
III. The CASE For A FIRST AMENDMENT RIGHT OF ACCESS TO CHILd CUSTODY AND DEPENDENCY PROCEEDINGS

Despite the different results reached by some lower courts, proper application of the two-part test shows that the right of access does indeed encompass custody and dependency cases. First, divorce proceedings and juvenile courts, the two forums in which judges typically make child custody determinations, have been historically open to the public. Second, openness improves custody proceedings because it serves to protect several important societal interests.

\section{A. The Historical Tradition of Openness}

Contrary to the conclusions of some courts, an examination of history reveals that child custody determinations have traditionally been open to the public. At least since the nineteenth century, statutes in England and America have given divorce courts jurisdiction over child custody disputes. ${ }^{64}$

An 1891 treatise on marriage and divorce states:

As a general rule, wherever the common law prevails, trials in all causes are in open court, to which spectators are admitted. This method is regarded as required for the purity of our judicial system, and as a precaution against possible injustice. In reason and in the ordinary practice, it extends to divorce causes. ${ }^{65}$

Several states enacted statutes codifying the common law rule requiring open hearings. By 1931, for example, nineteen states had statutes governing access to divorce proceedings. ${ }^{66}$ Five expressly required, or were judicially construed to require, that all divorce proceedings be open. ${ }^{67}$ Virginia law stated that courts

G4 By 1900, United States courts were handing down more than 55,000 divorce decrees each year, many of which included child custody determinations. Michael Grossberg, Governing the Hearth: Law and the Family in Nineteenth Century America 250-51 (North Carolina, 1985). See also Joel Prentiss Bishop, 2 Marriage and Divorce § 530 at 427 (Little, Brown, 4th ed 1864) (stating that custody determinations are made during divorce suits by the divorce court in its discretion).

65 Joel Prentiss Bishop, 2 Marriage, Divorce, and Separation $\$ 674$ at 278 (T.H. Flood, 1891) (footnotes omitted).

66 Chester G. Vernier, 2 American Family Laws: A Comparative Study of the Family Law of the Forty-eight American States, Alaska, the District of Columbia, and Hawaii (to Jan. 1, 1931) § 85 at 132 (Stanford, 1932).

${ }_{67}$ Id. Hawaii law required that "no [divorce] case shall be heard except openly in the public court-room." Hawaii Rev Laws $\S 2966$ (Honolulu Star-Bulletin 1925), repealed by 
"may" require parties to give divorce testimony in open court. ${ }^{68}$ Eleven states required openness in most divorce proceedings and permitted private hearings in exceptional cases only. ${ }^{69}$ Pennsylvania permitted private proceedings "if necessary." Finally, the only state that provided, in general, for private proceedings also gave courts discretion to hold them publicly, ${ }^{71}$ and courts sometimes did open the proceedings to the public. ${ }^{72}$

A number of cases decided during the late nineteenth and early twentieth centuries reveal the importance courts placed on openness. For example, in Hall v Hall, a 1916 divorce proceeding, an Illinois court ruled that a state statute expressly requiring

Act of May 11, 1965, 1965 Hawaii Sess Laws 68, No 76. An Mllinois statute required "examination of witnesses in open court" in divorce cases in which the defendant defaults, IIl Rev Stat ch 40, II 9 (Callaghan 1927), recodified as amended at 750 ILCS 5/405 (Michie 1993), and was construed by the Hlinois Court of Appeals to extend to contested cases as well. Hall $v$ Hall, $201 \mathrm{Ill}$ App 589 (1916). Iowa law stated that "all [divorce] actions shall be heard in open court ...." Iowa Code $\S 10472$ (1927), recodified as amended at Iowa Code Ann $\$ 598.8$ (West 1981). Michigan provided that "the testimony of either party to [a divorce] action shall be taken only in open court . . . Mich Comp Laws § 12759 (1929), repealed by Act of July 29, 1971, 1971 Mich Pub Acts 127, No 75. South Dakota's statute, which stated that contested divorce cases "shall be had at a regular term of court," was titled, "Trial in Public at Regular Term." SD Rev Code $\S 159$ (Hipple 1919), repealed by Act of Feb 7, 1945, 1945 SD Laws 54 ch 48.

63 Va Code Ann $\$ 5109$ (Michie 1930), recodified as amended at Va Code Ann § 20-106 (Michie 1990).

${ }_{69}$ Vernier, 2 American Family Laws $\S 85$ at 133 (cited in note 66). These states were Arizona, California, Georgia, Idaho, Mississippi, Montana, Nevada, New York, Utah, Vermont, and West Virginia. Id. The statutes, which varied from state to state, in general gave the courts discretion to exclude the public under certain circumstances, such as when the testimony was "scandalous or obscene" or "where the public interest require[d]." Id. In addition, some state statutes imposed restrictions on which groups the courts could exclude. See, for example, Ariz Rev Code Ann $\$ 3821$ (Bancroft-Whitney 1928), recodified as amended at Ariz Rule Civ Proc 80(b) (In all Superior Court cases, including divorces, "[w] hen a cause of a scandalous or obscene nature is to be tried, the court or referee may exclude from the court room all minors whose presence is not necessary as parties or witnesses."). In addition to the Arizona law, the Georgia, Idaho, Mississippi, Montana, Nevada, New York, Vermont, and West Virginia statutes remain in effect with amendments. See Ga Code Ann § 9-10-3 (Michie 1982); Idaho Rule Civ Pro 77(b); Miss Code Ann §§ 935-17, 93-5-23 (Law Co-op 1994); Mont Code Ann § 3-1-313 (1993); Nev Rev Stat § 125.080 (1991); NY Domestic Rel Law § 235 (McKinney 1986); NY Judiciary Law \& 4 (McKinney 1983); Vt Rule Fam Proc 4(g)(4); W Va Code Ann §§ 48-2-24, 48-2-25 (Michie 1992).

${ }_{70}$ Act of May 2, 1929, $1929 \mathrm{~Pa}$ Laws 1237, No $430 \& 27$, suspended by Pa Rulè Civ Proc 1459 (1949), repealed by Divorce Code, 1980 Pa Laws 63, No $26 \S 801$.

${ }_{11}$ Act of March 23, 1927, 35 Del Laws 564 ch 187 (1927), codified at Del Rev Code § 3514 (Star 1935), recodified as amended at 13 Del Code Ann \& 1516(a) (Michie 1993) ("All hearings and trials ... shall be had before the Court privately in Chambers; provided that, for reasons appearing sufficient to the Court, the hearing and trial in any particular case may be public.").

72 See, for example, Lecates $v$ Lecates, 38 Del 190, 190 A 294, 296 (Super Ct 1937) (holding that a court properly exercised its discretion to open divorce proceedings to the public, despite statute providing, in general, for private hearings). 
open divorce proceedings in default cases must extend to contested cases as well. ${ }^{73}$ Prior to the statute's enactment, courts could hold divorce hearings in private. The court stated that "[t]his practice gave rise to much scandal in divorce cases and gave to Chicago the reputation of being a mecca for disgruntled and dissatisfied married people, where divorce was speedily accomplished." Thus, to rid the courts of the "scandal" associated with private divorce proceedings, the court held that open hearings were mandatory in divorce cases. ${ }^{75}$

Similarly, in Harkins $v$ Harkins, the Supreme Court of Iowa held that a state statute governing divorce proceedings made it improper for a court to hear evidence behind closed doors. ${ }^{76}$ The court stated, "The statute provides that all such actions shall be heard in open court. And the court has no power to hear them otherwise, and should never do so." ${ }^{.77}$ Additionally, in Lecates $v$ Lecates, the Delaware Supreme Court held that, despite a statute providing in general for private divorce proceedings, a court could properly order that divorce proceedings be held publicly. ${ }^{78}$ The court emphasized that "court proceedings in private [seem] contrary to that conception of justice which has obtained for centuries among English speaking people"79 and that "the truth would better be discovered by an open hearing." ${ }^{\prime 80}$

Courts in Great Britain reported similar decisions, and at least two British cases appear to have had some influence in the United States. One such case, Scott $v S$ cott, ${ }^{81}$ was cited by the Delaware court in Lecates and was reported in detail in Professor John Henry Wigmore's treatise on Anglo-American evidence law. ${ }^{82}$ In Scott, a 1913 divorce action concerning a husband's impotence, the court held that English courts had no power to

201 กl App 589, 591-92 (1916).

74 Id at 590-91.

75 Id at 591.

$7699 \mathrm{NW} 154,154$ (Jowa 1904).

77 Id (citation omitted). The court further stated that although a court may exclude minors from divorce proceedings, "that the general public cannot be excluded from such trials is clear." Id.

${ }^{78} 38$ Del 190, 190 A 294, 296 (Super Ct 1937).

79 Id at 295 .

80 Id at 296. See also Cross $v$ Cross, 55 Mich 280, 21 NW 309, 310 (1884) (holding that a party to a divorce suit shall be examined only in open court); Hobart $v$ Hobart, 45 Iowa 501, 504 (1877) (holding that divorce actions must be publicly tried in open court).

811913 App Cas 414.

B2 See Lecates, $190 \mathrm{~A}$ at 295; Wigmore, 6 Evidence $\S 1834(2)$ at $439-40$ (cited in note 15) (1976 edition); John Henry Wigmore, 6 Evidence $\S 1834(2)$ at 335-36 (Little, Brown, 3d ed 1940) (1940 edition). 
hear divorce cases in chambers. ${ }^{83}$ A second British divorce case, McPherson $v$ McPherson, ${ }^{84}$ also received prominent attention in Wigmore's treatise. ${ }^{85}$ The McPherson court held that a divorce proceeding conducted in a judge's law library was improperly closed. ${ }^{86}$ Lord Blanesborough stated that a rule requiring openness is essential to divorce cases because some judges may tend to sympathize with parties requesting privacy:

[T] ] cies more effectively than to require that the trial of these cases shall always take place, and in the fullest sense, in open court. This requirement must be insisted upon because there is no class of case in which the desire of parties to avoid publicity is more widespread. There is no class of case in which in particular circumstances, it can be so clearly demonstrated even to a judge that privacy in that instance would be both harmless and merciful. ${ }^{87}$

Moreover, the virtues of openness held special importance in divorce suits involving custody determinations. Lord Blanesborough stated that openness is especially important where children are involved:

[T] invests the proceedings with some degree of formality. And formality is, perhaps, the only available substitute for the solemnity by which, ideally at all events, such proceedings, especially where the welfare of children is involved, should be characterized. That potential presence is at least some guarantee that there shall be a certain decorum of procedure. ${ }^{88}$

The British rule requiring openness, reported extensively in a treatise read widely in the United States and cited in at least one American state decision, no doubt influenced United States courts.

In summary, an examination of historical tradition indicates that United States divorce proceedings, where custody determi-

83 1913 App Cas at 417, 439-40, 445 .

34 1936 App Cas 177 (PC 1935).

${ }^{85}$ See Wigmore, 6 Evidence $\S 1834(2)$ at $440-41$ (cited in note 15) (1976 edition);

Wigmore, 6 Evidence $\S 1834$ (2) at 336-37 (cited in note 82) (1940 edition).

${ }_{86} 1936$ App Cas at 200-01.

${ }^{87}$ Id at 201.

${ }^{83}$ Id at 202. 
nations are typically made, have been largely open to the public. Courts believed that open proceedings protected the public's interest in maintaining the institution of marriage and the individual parties' interests in fairness, as well as the welfare of children. Although some states have provided by statute ${ }^{89}$ or judicial decision ${ }^{90}$ that access to divorce proceedings may be denied, most courts have rejected this view and continue to open divorce cases to the public. ${ }^{91}$ Such courts have recognized that the public has an interest in open courts and therefore that litigants "are not entitled to a private court proceeding just because they are required to use the judicial system. ${ }^{192}$

Because divorce courts do not make all custody decisions, however, it is also necessary to investigate the history of juvenile courts, which often decide custody in cases involving parental abuse or neglect. ${ }^{93}$ Although the history of openness in juvenile courts is not as strong as it is in divorce courts, courts have recently come to recognize the benefits of an open courtroom.

The first state juvenile court system was founded in 1899 on the belief that it was proper to rehabilitate rather than punish children. ${ }^{94}$ Since their creation, juvenile courts have allowed "varying degrees of public access." ${ }^{95}$ Although some juvenile

59 See, for example, Idaho Rule Civ Proc 77(b); Iowa Code Ann $\$ 598.8$ (West 1981); NY Judiciary Law § 4 (McKinney 1983); Utah Code Ann \$ 78-7-4 (Michie 1992). For a more complete list, see Wigmore, 6 Evidence $\$ 1835$ (1) at 445-47 n 2 (cited in note 15).

so See, for example, English v McCrary, 328 S2d 257, 259-60 (Fla Dist Ct App 1976), aff'd, 348 S2d 293 (Fla 1977).

91 See, for example, In re Keene Sentinel, $136 \mathrm{NH}$ 121, 612 A2d 911, 916-17 (1992) (holding that there is a presumption of openness to divorce proceedings and records); Barron, 531 S2d at 116-19 (granting the press access to sealed divorce files based on a common law right of access); George W. Prescott Publishing Co. $v$ Register of Probate for Norfolk County, 395 Mass 274, 479 NE2d 658, 663 (1985) (holding that in divorce cases-at least those involving public officials-openness of court records is presumed unless the overriding-interest standard of Press-Enterprise $I$ is met).

\$2 Barron, 531 S2d at 119. See also Scott, 1913 App Cas at 438 (A court may not close a divorce trial to the public merely because "the parties agree in being reluctant to have their case tried with open doors."); Comment, The First Amendment Right of Access to Civil Trials After Globe Newspaper Co. v. Superior Court, 51 U Chi L Rev 286, 294-98, 310-13 (1984) (arguing that the First Amendment right of access extends to civil trials, including divorce proceedings).

$\because$ See, for example, T.R., 556 NE2d at 442.

94 The Illinois Juvenile Court Act established the nation's first statewide special court for children. See Gilbert Cosulich, Juvenile Court Laws of the United States: Topical and State by State Summaries of Their Main Provisions 7-8 (National Probation Association, 2d ed 1939); Grossberg, Governing the Hearth at 279 (cited in note 64); Note, Press Access to the Juvenile Courtroom: Juvenile Anonymity and the First Amendment, 17 Colum J L \& Soc Probs 287, 290-92 (1982).

${ }_{95}$ Note, The Public Right of Access to Juvenile Delinquency Hearings, 81 Mich L Rev 1540,1552 (1983). 
courts have held their hearings in private,$^{96}$ others have allowed a substantial amount of public access. ${ }^{97}$ Many states have enacted statutes permitting "interested persons" to observe juvenile proceedings. ${ }^{98}$ The presence of "interested persons"-who may include students, social workers, lawyers, and others unconnected to the case at hand-substantially undermines the confidentiality that closure aims to secure. ${ }^{99}$ Thus, the history of openness in juvenile courts has been mixed; unlike divorce proceedings, there is no single tradition of either openness or closure.

In the past few decades, with a growing awareness of certain flaws in the juvenile court system ${ }^{100}$ and of the virtues of open-

${ }^{96}$ See id at $1552 \mathrm{n} 72$, citing Cosulich, Juvenile Court Laws of the United States at 50 (cited in note 94) (In 1939, juvenile courts in six states and the District of Columbia were closed to the public, while juvenile courts in twenty-four states were permitted to exclude the public.). See also Thomas Murphy, History of the Juvenile Court of Buffalo, in Children's Courts in the United States: Their Origin, Development, and Results, HR Rep No 701, 58th Cong, 2d Sess 10, 10 (1904) (Only the "defendants, the complainants, and the court officers and witnesses" were permitted to attend trials in New York.); Ben B. Lindsey, Additional Report on Methods and Results, in Children's Courts in the United States: Their Origin, Development, and Results, HR Rep No 701, 58th Cong, 2d Sess 47, 80 (1904) (Some sessions of juvenile court were held in the judge's chambers, "the probation officer being present with his reports, also the parents and only those interested."); In $r e$ J.S., $140 \mathrm{Vt} \mathrm{458,} 438 \mathrm{~A} 2 \mathrm{~d}$ 1125, 1127 (1981) (denying public access to juvenile court proceedings because, "[f]ar from a tradition of openness, juvenile proceedings are almost invariably closed"); Smith v Daily Mail Publishing Co., 443 US 97, 107 (1979) (Rehnquist concurring) (stating that juvenile proceedings historically have been closed to the public).

${ }^{97}$ See Note, 81 Mich L Rev at $1552 \mathrm{n} 72$ (cited in note 95); Richard S. Tuthill, History of the Children's Court in Chicago, in Children's Courts in the United States: Their Origin, Development, and Results, HR Rep No 701, 58th Cong, 2d Sess 10, 10 (1904) (juvenile hearings held in open court); Charlotte C. Eliot, The Change Wrought by the Juvenile Probation System in St. Louis, in Children's Courts in the United States: Their Origin, Development, and Results, HR Rep No 701, 58th Cong, 2d Sess 162, 162 (1904) (observers permitted to attend the first session of the juvenile court in St. Louis).

${ }_{93}$ See, for example, Minn Stat Ann § 260.155(1)(c) (West 1992 \& Supp 1995); Ky Rev Stat Ann § 208A.110(1) (Michie 1982); Cal Welfare \& Institutions Code § 676(a) (West 1984 \& Supp 1995).

${ }_{99}$ See In re Chase, 112 Misc 2d 436, 446 NYS2d 1000, 1007 (Fam Ct 1982) ("Frequent attendance by students, social-workers, lawyers, and observers of the court system indicates that one need not be 'interested' in the child in order to qualify as an interested person."”).

100 One commentator has written: “The [juvenile court] system's failure to control or reform juveniles has caused many to advocate that it be abolished or drastically reformed." Note, Associated Press v. Bradshaw: The Right of Press Access Extended to Juvenile Proceedings in South Dakota, 34 SD L Rev 738, 753 (1989). The Supreme Court itself has noted the possibility of juvenile court misconduct: "Too often the juvenile court judge falls far short of that stalwart, protective, and communicating figure the system envisaged." McKeiver v Pennsylvania, 403 US 528, 544 (1970). The Court also noted that “[a] recent study of juvenile court judges . . revealed that half had not received undergraduate degrees; a fifth had received no college education at all; a fifth were not members of the bar." Id at $544 \mathrm{n} 4$ (ellipsis in original), quoting President's Commission on Law Enforcement and Administration of Justice, Task Force Report: Juvenile Delinquency 
ness in judicial proceedings in general, ${ }^{101}$ some of the juvenile courts that had previously favored closure have opened their doors. ${ }^{102}$ Additionally, some states have enacted statutory provisions creating a presumption of openness. In Washington, for example, a statute provides that "[t]he general public and press shall be permitted to attend any hearing unless the court, for good cause, orders a particular hearing to be closed." ${ }^{103}$ Similarly, Michigan's statute provides for openness except under limited circumstances, ${ }^{104}$ and in Mlinois the juvenile courts are closed to the general public, but open to "the news media and the victim." 105 While these recent state statutes do not mandate openness, they represent a trend in states to presume openness and allow closure only in certain circumstances.

and Youth Crime 7 (US GPO, 1967). In addition, the Supreme Court has stated: "Although the juvenile-court system had its genesis in the desire to provide a distinctive procedure and setting to deal with the problems of youth, including those manifested by antisocial conduct, our decisions in recent years have recognized that there is a gap between the originally benign conception of the system and its realities." Breed $v$ Jones, 421 US 519, 528 (1975).

${ }^{101}$ See Wigmore, 6 Evidence $\S 1835(2)$ at 450 (cited in note 15) ("No court of justice can afford habitually to conduct its proceedings strictly in private.... The tendency to undue privacy should be checked.").

102 For a discussion of the trend toward greater press access to juvenile courts, see Paul R. Kfoury, Children Before the Court: Reflections on Legal Issues Affecting Minors 6365 (Butterworth, 2d ed 1991); Joseph B. Sanborn, The right to a public jury trial: a need for today's juvenile court, 76 Judicature 230, 233 (1993). See also People $v$ Williams, 97 Misc 2d 24, 410 NYS2d 978, 986 (County Ct 1978) (indicating that the protection of the juvenile offender's anonymity "should be subordinated to the community's need to observe the workings of its justice system ....").

${ }_{103}$ Wash Rev Code Ann \$ 13.40.140(6) (West 1993).

${ }_{104}$ The statute provides in part:

Upon motion of any party or victim, the court may close the hearing of a case brought pursuant to this chapter to members of the general public during the testimony of a child witness or victim if the court finds that closing the hearing is necessary to protect the welfare of the child witness or victim.

Mich Comp Laws Ann $\$$ 712A.17(7) (West 1993).

${ }_{105} 705$ ILCS 405/1-5(6) (Michie 1993 \& Supp 1994). The statute states:

The general public except for the news media and the victim shall be excluded from any hearing and, except for the persons specified in this Section, only persons, including representatives of agencies and associations, who in the opinion of the court have a direct interest in the case or the work of the court shall be admitted to the hearing.

Id. But see In re A Minor, 205 II App 3d 480, 563 NE2d 1069, 1074-75 (1990), aff'd, 149 IIl 2d 247, 595 NE2d 1052 (1992) (holding that juvenile proceedings are not presumptively open and that the press has only a conditional right of access under the nlinois statute). The court stated, "In our view, the language of section 1-5(6) suggests the legislature intended to give trial courts control over persons admitted to juvenile court hearings." 563 NE2d at 1075. 
It is important to note that in two cases the Supreme Court has found that proceedings have traditionally been open despite the existence of some periods of closure. In Press-Enterprise II, Chief Justice Burger relied on the 1807 trial of Aaron Burr to conclude that preliminary hearings have been traditionally open ${ }^{106}$-even though historical evidence indicates that when the framers drafted the First Amendment, preliminary hearings were closed. ${ }^{107}$ In addition, the majority in Globe Newspaper ignored "a long history of exclusion of the public from trials involving sexual assaults, particularly those against minors, ${ }^{108}$ and found a long tradition of openness in criminal trials. ${ }^{109}$

These two cases indicate that when a proceeding's history is ambiguous with respect to public and press access, periods of openness should be given more weight than periods of closure. That approach serves the First Amendment's underlying purposes. ${ }^{110}$ Indeed, the checking value of the First Amendment would be extinguished if the government and courts could pursue "policies and practices that reduce the amount and quality of information disseminated to the public ... simply because they serve the convenience, or embody the traditional prerogatives, of the government."111

\section{B. How Access Can Improve Child Custody and Dependency Proceedings}

The second prong of the Press-Enterprise II test requires an inquiry into the societal benefits of a right of access. ${ }^{112}$ It is quite clear and widely acknowledged that access to custody and dependency cases can play a significant role in the functioning and improvement of both the judicial process and the government as a whole. Indeed, as with criminal proceedings, public access to

106478 US at 10.

107 See Gannett Co., Inc. v DePasquale, 443 US 368, 387 (1979); Note, Press-Enterprise, Inc. v. Superior Court of California for the County of Riverside, 24 Am Crim L Rev 379, 399 (1986); Casenote, Newspaper Wins Court Access but Loses by a Qualifying Margin, 8 Loyola Ent L J 337, 345-46 (1988).

${ }_{108} 457$ US at 614 (Burger dissenting).

109 Id at 605.

110 See Comment, $51 \mathrm{U}$ Chi L Rev at 291 (cited in note 92); Note, 81 Mich I Rev at 1552 (cited in note 95 ).

"11 Vincent Blasi, The Checking Value in First Amendment Theory, 1977 Am Bar Found Res J 521, 609. Professor Blasi further states that public officials who enjoy relative immunity from public skepticism and occupy positions of power can inflict serious damage unless their behavior is regulated by public scrutiny. Id at 540-41.

112478 US at $11-13$. 
custody and dependency cases is essential to at least six fundamental democratic interests. ${ }^{113}$

First, public and press access to custody and dependency proceedings promotes free discussion of governmental affairs by educating and informing the public about the judicial system. ${ }^{114}$ Many courts have supported this proposition, one court noting that access to custody cases "can promote informed public discussion and lead to more intelligent responses to problems and issues." ${ }^{\text {115 }}$ As a whole, the standards governing the intrusion of the state into private family matters are still undefined. ${ }^{116}$ In custody cases in particular, the need for public scrutiny is especially acute because "the best interest of the child standard is inherently indeterminate."117 Public access to juvenile proceedings is also important because many judges deciding custody and dependency proceedings are elected officials: the public has a right to observe and evaluate their performance in office so that it can vote intelligently. ${ }^{118}$

Second, as in the criminal context, public and press access to custody determinations provides assurance that the proceedings are conducted fairly to all concerned. ${ }^{119}$ Even if all courts con-

113 See Dan Paul and Richard J. Ovelmen, Access, in 1 Communications Law 1993 79, 98-99 (Practicing Law Institute, 1993).

114 See T.R., 556 NE2d at 450; In re N.H.B., 769 P2d 844, 849 (Utah App 1989); In re Shortridge, 99 Cal 526, 34 P 227, 228-29 (1893); Wigmore, 6 Evidence $\$ 1834(2)$ at 438 (cited in note 15); Barron, 531 S2d at 116. See also Alexander Meiklejohn, Political Freedom: The Constitutional Powers of the People 9, 19 (Harper, 1960) ("The freedom of mind which befits the members of a self-governing society ... can be increased ... by the unhindered flow of accurate information .....").

115 T.R., 556 NE2d at 451. In T.R., the court stated that through access, "[t]he public would be educated in the decision-making processes of the juvenile court." Id at 453 . The court in San Bernardino County Department of Public Social Services $v$ Superior Court made a similar point: "[T] he press can assist juvenile courts in becoming more effective instruments of social rehabilitation by providing the public with greater knowledge of juvenile court processes, procedures, and unmet needs." 232 Cal App 3d 188, 283 Cal Rptr 332, 345 (1991), quoting Brian W. v Superior Court, 20 Cal 3d 618, 143 Cal Rptr 717, 719 (1978). See also M.R. $v$ Florida Department of Health and Rehabilitation Services, 19 Media L Rptr (BNA) 1189, 1190 (Fla Cir Ct 1991); In re Hill, 15 Media L Rptr (BNA) 1414, 1415 (Wash Super Ct 1988); Note, 34 SD L Rev at 755 (cited in note 100).

116 See Comment, 51 U Chi L Rev at 309 (cited in note 92), citing Michael Wald, State Intervention on Behalf of "Neglected" Children: A Search for Realistic Standards, 27 Stan L Rev 985, 1000-01 (1975). In his article, Wald states that most state statutes define "neglect" in broad and vague language, thereby increasing the likelihood of unnecessary or harmful intervention into family life. Wald, 27 Stan L Rev at 1000-01.

117 Wardle, Blakesley, and Parker, 4 Contemporary Family Law \$ 39:06 at 33 (cited in note 2) (footnote omitted). In addition, one commentator has argued that the public's ignorance about the juvenile justice system has contributed to the fiscal problems the system faces. See Note, 81 Mich $L$ Rev at 1550 (cited in note 95).

118 See T.R., 556 NE2d at 453.

119 See Florida Freedom Newspapers, Inc. v Sirmons, 508 S2d 462, 464 (Fla Dist Ct 
ducted all custody proceedings fairly, if the public or the parties perceived unfairness much would be lost. As one pair of authors states:

[I]t is crucial that any custody proceeding not only be fair but also be so perceived by the contestants. This is especially necessary in matters of custody, not just because future parenting by the "loser" may depend upon it, but also because violence and/or child snatching may well ensue without it. ${ }^{120}$

Without assurances that judges actually base their decisions on the best interests of the child rather than on their hidden biases or other improper factors, the public cannot trust the quality of custody proceedings. Access assures the public and the parties themselves that the courts treat the children and parties to a dispute fairly.

Third, openness serves the people's right to know what happens in their courts. ${ }^{121}$ The Supreme Court has noted repeatedly that "[a] trial is a public event. What transpires in the court room is public property."122 Unless the proceedings of child custody cases are open to the public, the public will never understand how judges make such determinations or know the common law as it develops. As a result, potential litigants will find themselves disadvantaged because they are unable to understand court rules and procedures. ${ }^{123}$ Most fundamentally, even though

App 1987), aff'd, Barron v Florida Freedom Newspapers, Inc., 531 S2d 113 (Fla 1988); Wigmore, 6 Evidence $\$ 1834(2)$ at 438 (cited in note 15).

${ }_{120}$ Black and Cantor, Child Custody at 51 (cited in note 2).

${ }^{121}$ In re Shortridge, $34 \mathrm{P}$ at 228 ("In this country it is a first principle that the people have the right to know what is done in their courts."). See also Franklyn S. Haiman, Speech and Law in a Free Society 368-69 (Chicago, 1981):

Not only does the public need information to exercise its responsibilities of citizenship, but, in a most fundamental sense, data in the hands of government belongs to the public, having been collected through use of taxpayers' money and by the exercise of authority derived from the people as a whole. For government officials to hold back material from those to whom it belongs, without exceptionally good reason, is the height of presumptuousness.

${ }_{122}$ Craig $v$ Harney, 331 US 367, 374 (1947). See also In re Oliver, 333 US 257, 266-68 (1948) (describing "[t]he traditional Anglo-American distrust for secret trials"); Maryland $v$ Baltimore Radio Show, Inc., 338 US 912, 920 (1950) (Frankfurter dissenting from denial of certiorari) ("One of the demands of a democratic society is that the public should know what goes on in courts by being told by the press, to the end that the public may judge whether our system of criminal justice is fair and right."); Estes $v$ Texas, 381 US 532, 54142 (1965) ("the public has the right to be informed as to what occurs in its courts").

${ }^{123}$ See Cincinnati Post v Second District Court of Appeals, 65 Ohio St 3d 378, 604 
a particular child custody case may not directly affect the public at large, all acts of the judiciary "relat[e] to the functioning of government," a subject that the Supreme Court has stated lies at the core of the expressly guaranteed freedoms of the First Amendment. ${ }^{124}$

Fourth, access serves as a check on corrupt practices by exposing the judicial process to public scrutiny. ${ }^{125}$ The nature of custody and dependency proceedings suggests a compelling need to check the exercise of government power. Because child custody determinations rely heavily on judicial discretion, "the 'compliant, biased, or eccentric judge' [is] a particular hazard." ${ }^{\text {26 }}$ Furthermore, because appellate review of child custody cases is very limited, public scrutiny of the system takes on added importance as a check against judicial misconduct. ${ }^{127}$ Finally, because judges, not juries, decide custody and dependency cases, the parties are not able to appeal to the community conscience, as embodied in the jury, to protect against government oppression. These features of child custody and dependency proceedings, therefore, suggest an especially strong need for openness. ${ }^{128}$

\footnotetext{
NE2d 153, 155 (1992).

124 Richmond Newspapers, 448 US at 575.

${ }_{125}$ See id at 569; Nebraska Press Ass'n v Stuart, 427 US 539, 559-60 (1976); Sheppard v Maxwell, 384 US 333, 350 (1966). See also In re Chase, 112 Misc 2d 436, 446 NYS2d 1000, 1006 (Fam Ct 1982), quoting In re Gault, 387 US 1, 18 (1967) ("Juvenile Court history has again demonstrated that unbridled discretion, however benevolently motivated, is frequently a poor substitute for principle and procedure."); Florida Freedom Newspapers, $508 \mathrm{~S} 2 \mathrm{~d}$ at 464 ("A strong and independent judiciary is the bulwark of a free society. If there were no public access to proceedings before the trial judge, there would be no safeguard for judicial independence nor any assurance of judicial integrity."); Wigmore, 6 Evidence $\S 1834(2)$ at 438 (cited in note 15).

${ }_{123}$ Note, 81 Mich L Rev at 1550-51 (cited in note 95), quoting Duncan $v$ Louisiana, 391 US 145, 156 (1968).

${ }_{127}$ Wardle, Blakesley, and Parker, 4 Contemporary Family Law \$ 39:10 at 68-69 (cited in note 2). See also Jeff Atkinson, Criteria for Deciding Child Custody in the Trial and Appellate Courts, 18 Fam L Q 1, 39 (1984) (child custody cases are generally less likely to be reversed on appeal than are civil and criminal cases). Such facts should make it less likely that the losers in child custody cases will appeal at all.

${ }^{123}$ To the extent the press fulfills its checking role, custody proceedings may become less intimate and more formal, and therefore increased openness could undermine the delicate relationship between the judge and a child who is the subject of the dispute. Such increased formality, however, will enhance the integrity of the proceedings. See, for example, Globe Newspaper, 457 US at 606 (public access to criminal trials enhances the quality of the fact-finding process and fosters an appearance of fairness); Richmond Newspapers, 448 US at 569 (public access to criminal trials may discourage perjury, misconduct, and biased decisions); Oliver, 333 US 270 n 24 (public trials may come to the attention of witnesses unknown to the parties, who might come forward and give important testimony); Gault, 387 US at 25-29 (concluding that more formal proceedings are consistent with the main goals of the juvenile court system).
} 
Fifth, access protects the right of parties involved in the custody dispute to a fair proceeding. As in the context of criminal trials, access to custody proceedings discourages perjury, misconduct of the parties, and decisions based on bias or partiality. ${ }^{129}$ As noted in Globe Newspaper, public presence at trials aids accurate fact-finding. ${ }^{130}$ Additionally, publicity may alert parents in general to their responsibilities toward their own children. ${ }^{131}$ Thus, openness may not harm the child in a dispute and may, in fact, benefit the child, the parties to the dispute, and society. ${ }^{132}$

Finally, open courtrooms will lead lawyers, witnesses, and judges to be more conscientious in the performance of their roles because they will know that their conduct is subject to public scrutiny. ${ }^{133}$ Indeed, custody proceedings may call for heightened public scrutiny because they make "extraordinary demands for compassion and sensitivity on the judge, the parties and the lawyers." 134

In summary, a right of access to custody cases is instrumental in improving child custody determinations. Access to custody cases serves the same interests that have led courts to recognize a right of access to criminal and civil proceedings.

129 See'Richmond Newspapers, 448 US at 569; Wigmore, 6 Evidence $\S 1834(2)$ at 438 (cited in note 15). Additionally, "inasmuch as there is no potential panel of veniremen to be tainted by undue publicity, open courtrooms present even less danger in juvenile matters than in criminal prosecutions." Florida Publishing Co. v Morgan, $253 \mathrm{Ga} 467,322$ SE2d 233, 238 (1984) (Weltner dissenting).

${ }^{130} 457$ US at 606 . See also Richmond Newspapers, 448 US at 596 (Brennan concurring) ("TM] istakes of fact in civil litigation may inflict costs upon others than the [parties].").

${ }^{131}$ See Note, 81 Mich L Rev at 1558 (cited in note 95).

132 Believing that favorable publicity would benefit the young girl at the center of the dispute, one of the parties to the custody battle in T.R. wrote and distributed a press release. $556 \mathrm{NE2d}$ at $442-43$. The court quoted the writer as saying about the young girl: "She is never going to be harmed or have a hair on her head affected if millions of people are looking out for her best interests .... Id at 454. See also Bill Dickhaut, In re T.R.: Not in Front of the Children, Ky Children's Rts J 10, 20 (July 1991) (arguing that courts must recognize that openness can serve, as well as harm, the best interests of the child, since, "[i]f the stated goal of a custody suit is to find the best parent for the child, what better way to expose the weaknesses and frailties of the prospective parents than under the harsh glare of publicity?").

${ }^{133}$ See Brown \& Williamson Tobacco Corp. $v$ FTC, 710 F2d 1165, 1179 (6th Cir 1983) ("In either the civil or the criminal courtroom, secrecy insulates the participants, masking impropriety, obscuring incompetence, and concealing corruption."); Wigmore, 6 Evidence § 1834(2) at 438 (cited in note 15).

${ }^{134}$ English v McCrary, 328 S2d 257, 260 (Fla Dist Ct App 1976), aff'd, 348 S2d 293 (Fla 1977) (Smith concurring). 


\section{QUALIFYING THE FIRST AMENDMENT RIGHT OF ACCESS TO CHILD CUSTODY AND DEPENDENCY PROCEEDINGS}

The Supreme Court has consistently recognized that any First Amendment right of access to judicial proceedings is qualified rather than absolute. The right of access may be restricted in certain cases to protect overriding interests. ${ }^{135}$ Such restrictions, however, must be (1) necessitated by a compelling governmental interest; and (2) narrowly tailored to serve that interest. ${ }^{136}$

This Section discusses what constitutes a compelling governmental interest in child custody cases and argues that courts can narrowly tailor restrictions to protect that interest by granting the press "conditional access." In addition, this Section examines the constitutionality of "conditional access" and the costs associated with it. Finally, it presents some factors courts should consider when drawing the line between total and conditional access.

A. Compelling Governmental Interests and Narrowly Tailored "Conditional Access"

Opponents of access might argue that, despite having a qualified right of access, the press should nonetheless be prohibited generally from attending custody cases because protecting the privacy of children in all cases constitutes an overriding and compelling governmental interest. Indeed, in some cases-such as many of those involving child molestation-such a compelling interest does in fact exist. In Globe Newspaper, the Supreme Court stated that the government had a compelling interest in "safeguarding the physical and psychological well-being of a minor" victim of sexual abuse. ${ }^{137}$

However, not all custody cases involve child abuse, and even among those that do, not all warrant closure. Rather, as the Supreme Court stated in Globe Newspaper, the significance of a child's privacy interest varies with the individual child and the circumstances of the case. ${ }^{138}$ For example, in child custody dis-

135 See, for example, Press-Enterprise I, 464 US at 509-10; Globe Newspaper, 457 US at 606-07.

${ }^{236}$ Globe Newspaper, 457 US at 606-07.

137 Id at 607.

138 Id at 607-09. The Court stated: "Among the factors to be weighed are the minor victim's age, psychological maturity and understanding, the nature of the crime, the desires of the victim, and the interests of parents and relatives." Id at 608 (footnote omitted). 
putes, the privacy interests of a six-year-old child who was sexually molested by her parents will differ from the privacy interests of a sixteen-year-old child with high self-esteem, great maturity, and upright parents. Because there are serious concerns for the physical and psychological well-being of the first child, her privacy interests are quite possibly compelling enough to warrant at least some restrictions on press access; however, this is probably not the case with the second child. Given such variance, a mandatory rule requiring closure in all custody cases cannot be justified; instead, courts must determine on a case-by-case basis whether closure is necessary to protect a particular child.

Any restrictions imposed on the press to protect a compelling state interest must be narrowly tailored to serve that interest. ${ }^{139}$ As Globe Newspapers illustrates, blanket closure orders should not be permitted where the circumstances of the particular case affect the significance of the state's interest. Thus, a restriction is not narrowly tailored if it denies the press access to all aspects of a single proceeding (such as an entire child abuse trial) or if it denies the press access to one aspect of a large number of proceedings (such as all testimony by minors in cases involving allegations of sexual abuse):

Some jurisdictions have met the "narrowly tailored" requirement by granting the press "conditional access" to custody proceedings. Under a "conditional access" agreement, a court may grant the press access to child custody determinations provided that the journalists will tailor their reporting in a particular manner. For example, the court might allow members of the press to attend only if they agree not to disclose the names or publish photographs of the parties or witnesses. ${ }^{140}$ This approach aims to protect the child's welfare by shielding her identity while still allowing the press to expose the public to the workings of the system. ${ }^{141}$

139 Id at 606-07.

140 See, for example, In re A Minor, 149 Ill 2d 247, 595 NE2d 1052, 1052-53 (1992) (reporter admitted to proceeding only after signing a pledge not to reveal the identities of minor victims of abuse); In re Hughes County, 452 NW2d 128, 129-30 (SD 1990) (media access to juvenile proceeding conditional on an agreement not to publish "the names, pictures, place of residence or identity of any party involved").

141 See In re Chase, 112 Misc 2d 436, 446 NYS2d 1000, 1008 (Fam Ct 1982) ("Public access to juvenile trials need not affect the confidentiality of records, nor, indeed, need the anonymity of the juvenile be sacrificed.") (footnote omitted); A Minor, 595 NE2d at 1055 ("This court and courts throughout this country in published opinions identify minors in juvenile proceedings by their initials, or first name and an initial, so that their anonymity may be preserved. The same policy would not diminish the role of the media."). 


\section{B. "Conditional Access": Its Constitutionality and Costs}

Some critics of "conditional access" argue that it amounts to an unconstitutional prior restraint. ${ }^{142}$ The Supreme Court has stated that prior restraints are not unconstitutional per se, ${ }^{143}$ but that the First Amendment provides "special protection" against them. ${ }^{144}$ When faced with a potentially unconstitutional prior restraint, courts must balance the various interests at issue. ${ }^{145}$

The Illinois Supreme Court conducted this sort of balancing test in In re A Minor. ${ }^{146}$ In that case the court held that an order prohibiting the press from disclosing the names of the children was not an unconstitutional prior restraint. ${ }^{147}$ The court weighed the children's privacy interest, as well as the state's interest in protecting the children's privacy, against the press's interest in full and unfettered disclosure of information. ${ }^{148}$ The court concluded that, in the particular circumstances of that case, the children's privacy interest was compelling, but the press's interest in disclosing the children's identities was not. The court

142 See, for example, Comment, Delinquency Hearings and the First Amendment: Reassessing Juvenile Court Confidentiality Upon the Demise of "Conditional Access," 13 UC Davis L Rev 123, 145-48 (1979).

${ }_{103}$ Southeastern Promotions, Ltd. v Conrad, 420 US 546, 558 (1975). See also Seattle Times Co. $v$ Rhinehart, 467 US 20 (1984), in which the Supreme Court upheld a court order forbidding a newspaper from disseminating information obtained through pretrial discovery in a civil proceeding. The Court stated that "even though the broad sweep of the First Amendment seems to prohibit all restraints on free expression, this Court has observed that "[f]reedom of speech ... does not comprehend the right to speak on any subject at any time." Id at 31 (ellipsis in original), quoting American Communications Ass'n $v$ Douds, 339 US 382, 394 (1950).

14 Nebraska Press Ass'n v Stuart, 427 US 539, 556 (1976).

145 See Landmark Communications, Inc. v Virginia, 435 US 829, 842-43 (1978) (The court must "make its own inquiry into the imminence and magnitude of the danger said to flow from the particular utterance and then to balance the character of the evil, as well as its likelihood, against the need for free and unfettered expression. The possibility that other measures will serve the State's interests should also be weighed.").

Several courts have addressed the issue of whether conditional access constitutes an impermissible prior restraint and have concluded that it does not. See, for example, In re A Minor, 149 Ill 2d 247, 595 NE2d 1052, 1055-57 (1992); In re Hughes County, 452 NW2d 128, 134 (SD 1990). For a more thorough analysis of whether orders prohibiting the press from disclosing children's identities in juvenile proceedings constitute an unconstitutional prior restraint, see Note, Conditional Access to Juvenile Court Proceedings: A Prior Restraint or a Viable Solution?, 44 Wash U J Urban \& Contemp L 135 (1993).

146149 Ill 2d 247, 595 NE2d 1052 (1992).

147 Id at 1055 . The case involved two proceedings "to provide shelter and care" for minors abused by their parents. Id at 1052 .

148 Id at 1056. 
held, therefore, that the order prohibiting the press from identifying the children was constitutional. ${ }^{149}$

While the First Amendment permits courts to restrict the press in some cases by granting it only "conditional access," such restrictions do not come without a cost. Supporters of the conditional access approach argue that it adequately serves the interests of the press and public by allowing the press to report anything that it thinks is important, except the identities of the parties. In A Minor, the court stated that the newspaper

was free to report anything that it observed or heard, except the identity of the minors.... [P]rohibiting the newspaper from disclosing the minor victims' identities in no way interferes with the newspaper's constitutional role of acting as a conduit for the public in generating the free flow of ideas, keeping the public informed of the workings of governmental affairs, and checking abuses by public officials. ${ }^{150}$

The court's statement, however, goes too far. A news report that fails to provide the names of the people at center stage loses a measure of credibility. As the Seventh Circuit has stated, "[r]eporting the true facts about real people is necessary to 'obviate any impression that the problems raised in the [report] are remote or hypothetical."'151 Although conditional access may be constitutional and effective in protecting both the interests of the child and the interests of the press, courts should nonetheless hesitate before imposing restrictions on the press because they severely hamper its ability to fully inform the public about important matters.

\section{Drawing the Line between Unconditional and Conditional Access}

Press access should not be restricted in cases involving routine custody disputes. On the other hand, restricted access may be appropriate in many disputes involving allegations of child sexual abuse. In a majority of such abuse cases, "conditional

149 Id at 1056-57.

150 Id at 1057.

${ }^{151}$ Haynes $v$ Alfred A. Knopf, Inc., 8 F3d 1222, 1233 (7th Cir 1993), quoting Gilbert $v$ Medical Economics Co., 665 F2d 305, 308 (10th Cir 1981). In Haynes, Chief Judge Posner stated: "People who do not desire the limelight and do not deliberately choose a way of life or course of conduct calculated to thrust them into it nevertheless have no legal right to extinguish it if the experiences that have befallen them are newsworthy, even if they would prefer that those experiences be kept private." 8 F3d at 1232 . 
access" based on the press agreeing not to disclose the parties' identities would be sufficient. Further restrictions might be necessary, however, if the case involving sexual abuse also involved a celebrity family or took place in a small community in which nearly everyone knew each other. In such cases, the public would probably be able to identify the parties even from news reports that did not include their names. In those circumstances, the court might offer the parties further protection by prohibiting the press from covering the most sensitive parts of the proceeding-such as when a child must testify about the abuse, or when a judge asks a child if she would prefer to live with one parent rather than the other. ${ }^{152}$ In addition, if the child is particularly young, immature, or emotionally scarred, the court might find it necessary to further condition the press's access on an agreement not to interview the child.

While right-of-access determinations necessarily involve caseby-case analysis, these illustrations bring to light a few critical factors courts should always keep in mind as they decide whether to limit access to a child custody hearing. These factors include: the child's age and level of maturity, the nature of the hearing, whether sexual abuse is at issue, and the potential for future physical or psychological harm to the child.

\section{CONCLUSION}

The constitutional objectives that led the Supreme Court to establish a right of access to criminal proceedings apply with equal force to child custody and dependency cases. The right of access may be limited only by restrictions that are narrowly tailored to protect a child's privacy interest. In such cases, a court may grant the press conditional access by allowing coverage of the proceeding but prohibiting the press from disclosing the identity of the child, or perhaps a court may exclude the press from one aspect of a particular proceeding. Access promotes informed public discussion, fairness, and the appearance of fairness, and it

${ }_{152}$ See generally Ira Mark Ellman, Paul M. Kurtz, and Katharine T. Bartlett, Family Law: Cases, Texts, Problems 541-42 (Michie, 2d ed 1991). Some statutes require that a transcript of such in camera interviews be made a part of the record unless waived by the parties. See, for example, Minn Stat Ann \$ 518.166 (West 1990). See also Smith v Smith, 425 NW2d 854, 858 (Minn 1988) ("trial court erred by failing to make a record" of in camera interviews of children); Williams $v$ Cole, $590 \mathrm{SW2d} 908$ (Mo 1979) (" $[\mathrm{I}] \mathrm{f}$ the court exercises its discretion and interviews the children in chambers without causing a record to be made, error is presumed."). Other statutes do not require a record of the interview. See, for example, Ohio Rev Code Ann § 3109.04(B) (Banks-Baldwin 1993). 
leads to more intelligent responses to problems and issues involving custody proceedings. Access benefits children by improving the system that decides their fate. 